\title{
Analisis Efektivitas Penerimaan Pajak Bumi Dan Bangunan (PBB) di Kecamatan Tolangohula Kabupaten Gorontalo
}

Barmin Yusuf

Studi Pembangunan, Fakultas Ekonomi Universitas Gorontalo email: barminyusuf78@gmail.com

\begin{abstract}
Land and Building Tax is a potential source of revenue for the region as one of the direct taxes. Land and Building Tax is a central tax because the object is in the area, then the region gets a bigger share. In Gorontalo Regency, mainly Tolagohula Subdistrict, as in other parts of Indonesia, the land and property tax $(P B B)$ is one source of local revenue. The management of the land and building tax (PBB) in Tolangohula sub-district is expected to lead to the welfare of the people in Gorontalo Regency.

The purpose of this study is to determine how the effectiveness of tax revenue Earth and Building $(P B B)$ in District Tolangohula Gorontalo District. Using the Ratio of the effectiveness of Land and Building Tax revenues (PBB) shows the ability of local governments in mobilizing Land and Building Tax (PBB) in accordance with the targeted. The ability to obtain Land and Building Tax $(P B B)$ is categorized effective if this ratio reaches at least 1 or $100 \%$. Overall, the acceptance effectiveness of Land and Building Tax (PBB) in District Tolangohula Regency Gorontalo during the period of 2012 to 2014 is in the effectiveness category.
\end{abstract}

Keywords: Land and Building Tax, Effectiveness

\section{PENDAHULUAN}

Salah satu tujuan negara yang disepakati oleh para pendiri awal negara ini adalah mensejahterakan rakyat, menciptakan kemakmuran yang berasaskan kepada keadilan sosial. Untuk dapat mencapai tujuan ini, negara harus melakukan pembangunan di segala bidang. Sebagai sebuah negara yang berdasarkan hukum material atau sosial. Indonesia menganut prinsip pemerintahan yang menciptakan kemakmuran rakyat dalam hal ini, ketersediaan dana yang cukup untuk membiayai pembangunan merupakan faktor yang sangat penting guna mencapai tujuan yang diinginkan.

Indonesia termasuk negara yang berkembang, yang memiliki pendapatan dari berbagai sumber salah satunya yaitu berasal dari pemungutan pajak, baik pajak 
negara maupun pajak daerah yang menjadi sumber terbesar pendapatan negara kita berasal dari pemungutan pajak. Meskipun pemungutan pajak merupakan sumber terbesar untuk pendapatan kas negara dalam proses pemungutannya tidak jarang sekali mengalami kendala dan masalah seperti masalah minimnya pengetahuan masyarakat terhadap pemungutan pajak, masalah kesadaran masyarakat untuk menjadi Wajib Pajak yang bijak dengan membayar pajak kepada negara, serta masalah penunggakan pembayaran pajak di negara kita ini sangatlah banyak terjadi di beberapa tahun terakhir.

Pajak Bumi dan Bangunan dapat dimanfaatkan untuk berbagai fungsi penentuan kebijakan yang terkait dengan bumi dan bangunan. Pajak Bumi dan Bangunan merupakan sumber penerimaan yang sangat potensial bagi daerah sebagai salah satu pajak langsung. Pajak Bumi dan Bangunan merupakan pajak pusat karena obyeknya didaerah, maka daerah mendapat bagian yang lebih besar. Mengingat pentingnya peran Pajak Bumi dan Bangunan bagi kelangsungan dan kelancaran pembangunan, maka diperlukan penanganan dan pengelolaan yang lebih intensif. Penanganan dan pengelolaan tersebut diharapkan mampu menuju tertib administrasi serta mampu meningkatkan partisipasi masyarakat dalam pembiayaan pembangunan melalui pembayaran pajak. Penanganan dan pengelolaan pajak dapat diwujudkan salah satunya dalam pemungutan PBB diharapkan pelaksanaan pemungutan PBB sesuai dengan aturan undang-undang PBB yang berlaku saat ini yaitu Undang-Undang Nomor 12 Tahun 1984 sebagaimana telah diubah menjadi Undang-Undang Nomor 12 Tahun 1994 Tentang Pajak Bumi dan Bangunan.

Sebagaimana telah diubah menjadi Undang-Undang Nomor 12 Tahun 1994 Tentang Pajak Bumi dan Bangunan. Demi kelancaran serta keberhasilan dalam melakukan pelaksanaan pemungutan pajak harus didukung dan dijalankan oleh pihak Fiskus, yaitu Kantor Pelayanan Pajak Bumi dan Bangunan (KP PBB) yang ada di setiap Kabupaten di Indonesia dan para wajib pajak. Sebagai unit kerja modern, struktur organisasi KP PBB mengalami perubahan sesuai fungsi yang menggabungkan fungsi pelayanan Kantor Pelayanan Pajak (KPP), fungsi pelayanan Pajak Bumi dan Bangunan (PBB) dari KP PBB ke dalam satu atap pelayanan yaitu Kantor Pelayanan Pajak Pratama (KPP Pratama). Kedua pihak di atas saling berhubungan dan saling mempengaruhi terutama dalam hal proses pemungutan pajak. Dalam menjalankan fungsinya keduanya perlu mengetahui dengan jelas hakhak dan kewajiban masing-masing dan selanjutnya menerapkannya dalam praktek. Disini pihak yang menentukan dalam pemungutan PBB adalah fiskus. Dalam menjalankan hak dan kewajiban fiskus, untuk mencapai kinerja yang baik dan positif, fiskus harus dilakukan sesuai dengan prosedur dan peraturan yang berlaku, serta mengacu pada prinsip yang ada dalam tata pemerintahan yang baik (Good Governance). Dalam praktek berorganisasi, good governance biasanya dikaitkan dengan mekanisme pengawasan internal (internal control) yang bertujuan untuk meminimalkan terjadinya penyimpangan ataupun penyelewengan dalam organisasi, baik itu dilakukan oleh pegawai maupun pihak lainnya, baik disengaja maupun tidak. Good governance tidak hanya terbatas pada masalah integritas, tetapi juga menyangkut efisiensi dan efektivitas, serta profesionalisme dan akuntabilitas organisasi, sedangkan bagi para wajib pajak dalam menjalankan hak dan kewajibannya dengan tingkat kesadaran hukum yang tinggi diharapkan mematuhi aturan yang ada yaitu Undang-undang khususnya Undang-undang Nomor 12 Tahun 1994 Tentang Pajak Bumi dan Bangunan.

Di Kabupaten Gorontalo, utamanya Kecamatan Tolagohula, sebagaimana daerah lainnya di Indonesia, pajak bumi dan bangunan (PBB) merupakan salah satu 
sumber penerimaan daerah. Pengelolaan terhadap pajak bumi dan bangunan (PBB) di Kecamatan Tolangohula pada akirnya diharapkan akan berujung pada kesejahteraan masyarakat di Kabupaten Gorontalo.

Bertitik tolak dari uraian di atas maka perlu dikaji dan diteliti secara mendalam tentang "Analisis Efektivitas Penerimaan Pajak Bumi dan Bangunan di Kecamatan Tolangohula Kabupaten Gorontalo".

\section{KAJIAN TEORI}

\subsection{Pengertian Pembangunan Ekonomi}

Menurut Bintoro (2011 ; hal 1) pembangunan adalah suatu orientasi dan kegiatan tanpa aksi. Development is not a stoke concep.it is continously changing. Proses pembangunan sebenarnya adalah suatu perubahan sosial budaya.pembangunan supaya menjadi suatu proses yang dapat bergerak maju atas kekuatan sendiri tergantung pada manusia dan struktur sosialnya.

Menurut Siagian (2012 ; hal 41 ) pembangunman adalah usaha yang secara sadar di laksanakan oleh suatu bangsa negara dan pemerintah dalam rangka pembinaan bangsa.

\subsection{Konsep Penerimaan Daerah}

Barata dan Trihartanto (2013 : Hal 51) menjelaskan bahwa penerimaan atau pendapatan Negara (government revenue) adalah semua penerimaan kas umum (kas pemerintah pusat) atau kas daerah (kas pemerintah daerah) dari berbagai sumber yang sah, yang menambah ekuitas dana dalam periode tahun anggaran bersangkutan yang menjadi hak pemerintah pusat atau daerah.

Penerimaan daerah menurut Undang-undang RI Nomor 33 Tahun 2004 adalah uang yang masuk ke kas daerah. Sumber-sumber penerimaan daerah dalam pelaksanaan desentralisasi, yaitu :

a) Pendapatan Asli Daerah (PAD)

b) Dana perimbangan

c) Pinjaman daerah

d) Hasil kekayaan pengelolaan daerah lainnya yang dipisahkan

e) Lain-lain penerimaan yang sah

\subsection{Konsep Pajak}

Suparmoko (2010 : Hal 94) menjelaskan bahwa yang dimaksud dengan pajak adalah pembayaran iuran oleh rakyat kepada pemerintah yang dapat dipaksakan dengan tanpa balas jasa yang secara langsung dapat ditunjuk. Misalnya pajak kenderaan bermotor, pajak penjualan, dan lain sebagainya.

Adapun pengertian pajak menurut Sumitro sebagaimana dikemukakan oleh Darise (2011 : Hal 44) adalah iuran rakyat pada kas Negara berdasarkan undangundang (yang dipaksawsekan) dengan tiada mendapat jasa timbal balik (kontraprestasi) langsung yang dapat ditunjukan dan yang digunakan untuk membayar pengeluaran umum.

\subsection{Pajak Bumi Dan Bangunan (PBB)}

Menurut Soemitro (2006:1) Pajak Bumi dan Bangunan adalah pajak yang dikenakan atas harta tidak bergerak, oleh sebab itu yang dipentingkan adalah objeknya dan oleh karena itu keadaan atau status orang atau badan yang dijadikan subjek tidak penting dan tidak mempengaruhi besarnya pajak, maka disebut juga pajak objektif. Pajak Bumi dan Bangunan adalah salah satu pajak pusat yang merupakan sumber penerimaan Negara yang sebagian besar hasilnya diserahkan kepada Pemerintah Daerah untuk kepentingan masyarakat daerah tempat objek pajak. Dari peranan di atas, dapat disimpulkan bahwa pengertian PBB adalah iuran 
yang dikenakan terhadap orang atau badan yang secara nyata mempunyai hak, memiliki, menguasai dan memperoleh manfaat dari bumi dan bangunan. Namun sebagimana telah dirubah dengan UU No. 28/2009 tentang pajak daerah dan retribusi daerah yang baru, Pajak Bumi dan Bangunan kini merupakan Pajak Daerah yang $100 \%$ penerimaannya akan diterima oleh Daerah yang bersangkutan. Dimana selama ini PBB merupakan pajak pusat, namun hampir seluruh penerimaannya diserahkan kepada daerah. Untuk meningkatkan akuntabilitas pengelolaan keuangan daerah, khusus PBB sektor perdesaan dan perkotaan dialihkan menjadi pajak daerah. Sedangkan PBB sektor perkebunan, perhutanan, dan pertambangan masih merupakan pajak pusat. Dengan dijadikannya PBB Perdesaan dan Perkotaan menjadi pajak daerah, maka penerimaan jenis pajak ini akan diperhitungkan sebagai pendapatan asli daerah(PAD).

Subjek Pajak Bumi dan Bangunan adalah orang pribadi atau badan yang secara nyata :

a. Mempunyai suatu hak atas bumi, dan atau ;

b. Memperoleh manfaat atas bumi, dan / atau ;

c. Memiliki , menguasai atas bangunan , dan / atau ;

d. Memperoleh manfaat atas bangunan.

Ditinjau dari jenis pajaknya, Pajak Bumi dan Bangunan (PBB) merupakan pajak yang dikenakan atas bumi dan bangunan. Bumi merupakan permukaan bumi dan tubuh bumi yang ada dibawahnya, permukaan bumi yang meliputi tanah dan perairan pendalaman (termasuk rawa-rawa dan tambak perairan) serta laut wilayah Republik Indonesia. Menurut Mardiasmo (2002:271) dalam menentukan klasifikasi bumi dan bangunan, Menteri Keuangan harus memperhatikan faktor-faktor sebagai berikut:

a. Bumi/tanah:

1) Letak;

2) Peruntukan;

3) Pemanfaatan;

4) Kondisi;

b. Bangunan:

1) Bahan yang digunakan;

2) Rekayasa;

3) Letak;

4) Kondisi lingkungan dan lain-lain

\section{METODE PENELITIAN}

\subsection{Obyek Penelitian}

Berdasarkan objek judul penelitian yang diteliti, maka yang menjadi sasaran dan daerah penelitian adalah di Kecamatan Tolangohula Kabupaten Gorontalo. Waktu Penelitian yang digunakan adalah selama tiga bulan.

\subsection{Definisi Operasional}

Untuk mengarahkan penelitian ini, maka terlebih dahulu didefinisikan indikator operasional yang terkandung dalam obyek penelitian sehingga hasil yang diharapkan dalam penelitian ini dapat tercapai yaitu sebagai berikut :

1. Penerimaan Daerah adalah semua penerimaan kas umum atau kas daerah (kas pemerintah daerah) dari berbagai sumber yang sah, yang menambah ekuitas dana dalam periode tahun anggaran bersangkutan yang menjadi hak pemerintah daerah Kabupaten Gorontalo. 
2. Pajak Bumi dan Bangunan (PBB) adalah iuran yang dikenakan terhadap orang atau badan yang secara nyata mempunyai hak, memiliki, menguasai dan memperoleh manfaat dari bumi dan bangunan di Kecamatan Tolangohula Kabupaten Gorotalo.

\subsection{Metode Pengumpulan Data}

Untuk dapat mencapai tujuan penelitian dan untuk membuktikan kebenaran hipotesis yang telah diajukan dalam penulisan ini serta untuk mendapatkan informasi yang objektif, akurat dan dapat dipertanggungjawabkan, maka dilakukan metode pengumpulan data sebagai berikut

1. Penelitian Kepustakaan (Library Research) yaitu Penelitian yang dilakukan dengan mengutip beberapa literatur - literatur seperti : Buku - Buku, Majalah, Brosur, dan karangan lainnya yang erat hubungannya dengan permasalahan yang diteliti. Dengan kata lain penulis mengumpulkan data yang sifatnya dokumen sehubungan dengan objek yang akan diteliti.

2. Penelitian Lapangan (Field Researh)

a. Observasi

Yaitu dengan melakukan pengamatan serta pencatatan secara langsung dan terstruktur pada objek penelitian menyangkut variabel yang diangkat dalam penulisan ini.

b. Wawancara.

Selain itu dilakukan wawancara dengan pihak-pihak yang berkompeten dengan masalah yang diteliti.

c. Dokumentansi

Yaitu berupa upaya pengumpulan data melalui pencatatan dari berbagai dokumen yang mendukung penelitian atau bukti - bukti yang berhubungan dengan masalah yang diteliti.

\subsection{Jenis Dan Sumber Data}

1. Jenis Data

Dalam penelitian ini, ada dua jenis data yang dikumpulkan oleh peneliti guna menguji hipotesis yang diajukan, yaitu:

a) Data kuantitatif yang berupa berbagai jenis data dalam bentuk angkaangka.

b) Data kualitatif yaitu data yang dapat mendukung data kuantitatif dalam pemecahan kasus yang berupa penjelasan secara deskriptif terhadap berbagai faktor yang mempengaruhi dalam pemecahan kasus seperti informasi - informasi yang berkaitan dengan masalah

2. Sumber data

a. Data Primer

Yaitu data yang diperoleh langsung dari obyek penelitian baik melalui pengamatan maupun wawancara (interview)

b. Data Sekunder

Yaitu data yang telah ada pada obyek penelitian atau data hasil penelitian yang sudah pernah dilakukan sebelumnya, dimana data tersebut bersumber dari dokumen organisasi tersebut atau institusi lainnya, yang dianggap berkaitan atau relevan dengan masalah yang di bahas 


\subsection{Metode Analisis}

Metode analisis yang digunakan untuk membuktikan hipotesis yang diajukan serta untuk menganalisisi variabel yang diangkat, yaitu :

1. Metode kualitatif Yaitu menguraikan dan menganalisa data-data yang ditemukan di lapangan secara deskriptif.

2. Metode kuantitatif Untuk menghitung tingkat efektifitas pajak bumi dan bangunan dilakukan menggunakan rasio efektifitas pajak sebagaimana dikemukakan oleh Mahmudi (2010 : 129) yaitu dengan cara membandingkan realisasi penerimaan PBB dengan target penerimaan PBB. Rasio ini dirumuskan sebagai berikut :

\section{Rasio Efektifitas PBB = Realisasi Penerimaan PBB X 100\% Target Penerimaan PBB}

Rasio efektivitas Pajak Bumi dan Bangunan menunjukan kemampuan pemerintah daerah dalam mengumpulkan pajak daerah sesuai dengan yang ditargetkan. Kemampuan memperoleh pajak dikategorikan efektif apabila rasio ini mencapai minimal 1 atau $100 \%$.

Selanjutnya standar efektivitas yang ditetapkan melaui Peraturan Menteri Dalam Negeri no. 690.900-327 tahun 1994 adalah sebagai berikut :

- Koefisien efektivitas bernilai di bawah 40\% adalah sangat tidak efektif

- Koefisien efektivitas bernilai dari 40\% sampai dengan $60 \%$ adalah tidak efektif

- Koefisien efektivitas bernilai di atas 60\% sd. 80\% adalah kurang efektif

- Koefisien efektivitas bernilai di atas $80 \%$ sd. $90 \%$ adalah cukup efektif

- Koefisien efektivitas bernilai di atas 90\% sd. 100\% adalah efektif

- Koefisien efektivitas bernilai di atas 100\% adalah sangat efektif

\section{HASIL PENELITIAN DAN PEMBAHASAN}

\subsection{Target dan Realisasi Penerimaan Pajak Bumi dan Bangunan (PBB) Kecamatan Tolangohula Kabupaten Gorontalo}

Sebagaimana telah dijelaskan sebelumnya bahwa Pemungutan pajak bumi dan bangunan (PBB) di Kecamatan Tolangohula dilakukan oleh pemerintah desa, dibawah koordinasi langsung oleh pemerintah Kabupaten Gorontalo dalam hal ini adalah Dinas Pendapatan dan Pengelolaan Keuangan Daerah dan Pemerintah Kecamatan.

Adapun target penerimaan penerimaan Pajak Bumi dan Bangunan (PBB) di Kecamatan Tolangohula Kabupaten Gorontalo tahun 2012-2014 dirinci per desa yang dapat ilihat pada tabel dibawah ini : 
Tabel 5.4 Target Penerimaan Pajak Bumi dan Bangunan (PBB)

Kecamatan Tolangohula Tahun 2012-2014

\begin{tabular}{|c|c|c|c|c|}
\hline \multirow{2}{*}{ NO } & \multirow{2}{*}{ DESA } & \multicolumn{3}{|c|}{ TARGET } \\
\hline & & 2012 & 2013 & 2014 \\
\hline 1 & Gandasari & $23,369,074$ & $23,897,534$ & $22,469,908$ \\
\hline 2 & Sukamakmur & $16,304,063$ & $17,084,841$ & $13,342,446$ \\
\hline 3 & Molohu & $15,180,866$ & $15,852,925$ & $12,477,033$ \\
\hline 4 & Lakeya & $5,200,000$ & $5,306,789$ & $5,266,949$ \\
\hline 5 & Binajaya & $6,395,141$ & $6,983,943$ & $6,518,462$ \\
\hline 6 & Polohugo & $8,135,796$ & $8,393,043$ & $13,718,822$ \\
\hline 7 & Tamaila & $7,546,569$ & $8,007,968$ & $7,339,084$ \\
\hline 8 & Sidoharjo & $11,339,000$ & $10,500,000$ & $10,217,633$ \\
\hline 9 & $\begin{array}{l}\text { Sukamakmur } \\
\text { Utara }\end{array}$ & $14,253,054$ & $14,501,245$ & $12,650,413$ \\
\hline 10 & Margomulya & $16,009,701$ & $16,266,970$ & $13,620,472$ \\
\hline 11 & Makmur Abadi & $4,993,170$ & $5,543,855$ & $5,478,105$ \\
\hline 12 & Gandaria & $3,840,000$ & $4,305,502$ & $5,096,455$ \\
\hline 13 & Ombulotango & $6,798,438$ & $7,172,196$ & $6,891,097$ \\
\hline 14 & Tamaila Utara & $3,984,534$ & $4,495,057$ & $4,368,197$ \\
\hline 15 & Himalaya & $2,560,000$ & $2,802,383$ & $2,800,103$ \\
\hline & Jumlah & $145,909,406$ & $151,114,251$ & $142,255,179$ \\
\hline
\end{tabular}

Sumber Data : DPKAD Kabupaten Gorontalo Tahun 2016

Dari tabel 5.4 diatas dapat dilihat bahwa target yang ditetapkan oleh Pemerintah Daerah Kabupaten Gorontalo dalam hal penerimaan Pajak Bumi dan Bangunan (PBB) di Kecamatan Tolangohula Kabupaten Gorontalo pada tahun 2012 adalah sebesar Rp. 145.909.406,- kemudian pada tahun 2013 sebesar Rp. 151.114.251,- dan pada tahun 2014 target yang ditetapkan turun menjadi sebesar 142.255.179,. Adapun desa dengan target penerimaan PBB terbesar di Kecamatan Tolangohula adalah di Desa Gandasari, Sukamakmur, Margomulya, dan Desa Molohu serta terkecil di Desa Himalaya.

Adapun realisasi penerimaan daerah melalui Pajak Bumi dan Bangunan PBB di Kecamatan Tolangohula Kabupaten Gorontalo, pada tabel dibawah ini : 
Tabel 5.5 Realisasi Penerimaan Pajak Bumi dan Bangunan (PBB) Kecamatan Tolangohula Tahun 2012-2014

\begin{tabular}{|c|c|c|c|c|}
\hline \multirow{2}{*}{ NO } & \multirow{2}{*}{ DESA } & \multicolumn{3}{|c|}{ REALISASI } \\
\hline & & 2012 & 2013 & 2014 \\
\hline 1 & Gandasari & $11,760,000$ & $23,897,534$ & $22,469,908$ \\
\hline 2 & Sukamakmur & $6,000,000$ & $12,000,000$ & $13,342,446$ \\
\hline 3 & Molohu & $12,181,000$ & $15,852,925$ & $12,477,033$ \\
\hline 4 & Lakeya & $3,350,000$ & $5,306,789$ & $5,266,949$ \\
\hline 5 & Binajaya & $6,395,141$ & $6,983,943$ & $6,518,462$ \\
\hline 6 & Polohugo & $8,135,796$ & $8,393,043$ & $13,718,822$ \\
\hline 7 & Tamaila & $5,850,000$ & $8,007,968$ & $7,339,084$ \\
\hline 8 & Sidoharjo & $11,339,000$ & $10,500,000$ & $10,217,633$ \\
\hline 9 & $\begin{array}{l}\text { Sukamakmur } \\
\text { Utara }\end{array}$ & $12,358,000$ & $14,501,245$ & $12,650,413$ \\
\hline 10 & Margomulya & $16,009,701$ & $12,480,000$ & $13,620,472$ \\
\hline 11 & Makmur Abadi & $4,993,170$ & $5,543,855$ & $5,478,105$ \\
\hline 12 & Gandaria & $3,840,000$ & $4,305,502$ & $5,096,455$ \\
\hline 13 & Ombulotango & $5,446,000$ & $7,172,196$ & $6,891,097$ \\
\hline 14 & Tamaila Utara & $3,984,534$ & $4,495,057$ & $4,368,197$ \\
\hline \multirow[t]{2}{*}{15} & Himalaya & $2,250,000$ & $2,802,383$ & $2,800,103$ \\
\hline & Jumlah & $113,892,342$ & $142,242,440$ & $142,255,179$ \\
\hline
\end{tabular}

Sumber Data : DPKAD Kabupaten Gorontalo Tahun 2016

Dari tabel diatas dapat di lihat bahwa realisasi penerimaan Pajak Bumi dan Bangunan (PBB) di Kecamatan Tolangohula Kabupaten Gorontalo pada tahun 2012 adalah sebesar Rp. 113.892.342,-. Kemudian meningkat pada tahun 2013 menjadi sebesar Rp. 142.242.440,- Pada tahun selanjutnya yaitu tahun 2014 realiasi penerimaan PBB di Kecamatan Tolangohula kembali naik meski sedikit yaitu menjadi Rp. 142.255.179,. Adapun desa dengan realisasi penerimaan PBB terbesar di Kecamatan Tolangohula adalah di Desa Gandasari, Sukamakmur, Margomulya, dan Desa Molohu serta terkecil di Desa Himalaya.

Selanjutnya dapat dilihat perbandingan antara target dan realisasi penerimaan Pajak Bumi dan Bangunan (PBB) di Kecamatan Tolangohula Kabupaten Gorontalo, sebagai berikut : 
Tabel 5.6 Target Dan Realisasi Penerimaan Pajak Bumi dan Bangunan (PBB) di Kecamatan Tolangohula Kabupaten Gorontalo

\begin{tabular}{|c|c|c|c|c|c|c|c|}
\hline \multirow{2}{*}{ NO } & \multirow{2}{*}{ DESA } & \multicolumn{3}{|c|}{ TARGET } & \multicolumn{3}{|c|}{ REALISASI } \\
\hline & & 2012 & 2013 & 2014 & 2012 & 2013 & 2014 \\
\hline 1 & Gandasari & $23,369,074$ & $23,897,534$ & $22,469,908$ & $11,760,000$ & $23,897,534$ & $22,469,908$ \\
\hline 2 & kamakmur & $16,304,063$ & $17,084,841$ & $13,342,446$ & $6,000,000$ & $12,000,000$ & $13,342,446$ \\
\hline 3 & 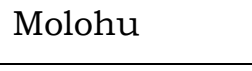 & $15,180,866$ & $15,852,925$ & $12,477,033$ & $12,181,000$ & $15,852,925$ & $12,477,033$ \\
\hline 4 & & $5,200,000$ & $5,306,789$ & $5,266,949$ & $3,350,000$ & $5,306,789$ & $5,266,949$ \\
\hline 5 & & $6,395,141$ & $6,983,943$ & $6,518,462$ & $6,395,141$ & $6,983,943$ & $6,518,462$ \\
\hline 6 & & $8,135,796$ & $8,393,043$ & $13,718,822$ & $8,135,796$ & $8,393,043$ & $13,718,822$ \\
\hline 7 & & $7,546,569$ & $8,007,968$ & $7,339,084$ & $5,850,000$ & $8,007,968$ & $7,339,084$ \\
\hline 8 & Sidu & 11,339 & $10,500,000$ & $10,217,633$ & $11,339,000$ & $10,500,000$ & $10,217,633$ \\
\hline 9 & kamakn & $14,253,054$ & $14,501,245$ & $12,650,413$ & $12,358,000$ & $14,501,245$ & $12,650,413$ \\
\hline 10 & Margom & $16,009,701$ & $16,266,970$ & $13,620,472$ & $16,009,701$ & $12,480,000$ & $13,620,472$ \\
\hline 11 & $\begin{array}{l}\text { Makmur } \\
\text { Abadi }\end{array}$ & $4,993,170$ & $5,543,855$ & $5,478,105$ & $4,993,170$ & $5,543,855$ & $5,478,105$ \\
\hline 12 & Gandaria & $3,840,000$ & $4,305,502$ & $5,096,455$ & $3,840,000$ & $4,305,502$ & $5,096,455$ \\
\hline 13 & Ombulotango & $, 798,438$ & $7,172,196$ & $6,891,097$ & $5,446,000$ & $7,172,196$ & $6,891,097$ \\
\hline 14 & $\begin{array}{l}\text { Tamaila } \\
\text { Utara }\end{array}$ & $3,984,534$ & $4,495,057$ & $4,368,197$ & $3,984,534$ & $4,495,057$ & $4,368,197$ \\
\hline 15 & Himalaya & $2,560,000$ & $2,802,383$ & $2,800,103$ & $2,250,000$ & $2,802,383$ & $2,800,103$ \\
\hline & Jumlah & $145,909,406$ & $151,114,251$ & $142,255,179$ & $113,892,342$ & $142,242,440$ & $142,255,179$ \\
\hline
\end{tabular}

Sumber : DPKAD Kabupaten Gorontalo Tahun 2016

Dari tabel 5.6 diatas dapat dilihat bahwa pada tahun 2012 taget penerimaan Pajak Bumi dan Bangunan (PBB) di Kecamatan Tolangohula Kabupaten Gorontalo adalah sebesar Rp. 145.909.406,- dan yang terealisasi adalah sebesar Rp. 151.114.251,- kemudian pada tahun 2013 target penerimaan sebesar Rp. 142.255.179 dan yang terealisasi adalah sebesar Rp. 113.892.342,- dan pada tahun 2014 target yang ditetapkan pemerintah sebesar sebesar Rp. 142.242.440,- dan yang terealisasi adalah sebesar Rp. 142.242.440,-

\subsection{Analisis Efektivitas Penerimaan Pajak Bumi dan Bangunan (PBB) di Kecamatan Tolangohula Kabupaten Gorontalo.}

Untuk menghitung tingkat efektifitas pajak bumi dan bangunan dilakukan menggunakan rasio efektifitas pajak sebagaimana dikemukakan oleh Mahmudi (2010) yaitu dengan cara membandingkan realisasi penerimaan PBB dengan target penerimaan PBB. Rasio ini dirumuskan sebagai berikut : 


\section{Rasio Efektifitas PBB $=$ Realisasi Penerimaan PBB $\times 100 \%$ \\ Target Penerimaan PBB}

Rasio efektivitas penerimaan Pajak Bumi dan Bangunan (PBB) di Kecamatan Tolangohula Kabupaten Gorontalo menunjukan kemampuan pemerintah daerah dalam memobilisasi penerimaan yang berasal dari Pajak Bumi dan Bangunan (PBB) di Kecamatan Tolangohula Kabupaten Gorontalo sesuai dengan yang ditargetkan. Kemampuan memperoleh Pajak Bumi dan Bangunan (PBB) di Kecamatan Tolangohula Kabupaten Gorontalo dikategorikan efektiv apabila rasio ini mencapai minimal 1 atau $100 \%$.

Dari penjelasan diatas, selanjutnya dapat dihitung efektivitas penerimaan Pajak Bumi dan Bangunan (PBB) di Kecamatan Tolangohula Kabupaten Gorontalo, yang dihitung dengan cara membagi realisasi penerimaan penerimaan Pajak Bumi dan Bangunan (PBB) dengan target penerimaan Pajak Bumi dan Bangunan (PBB) yang ditetapkan oleh pemerintah daerah Kabupaten Gorontalo.

Perhitungan tentang efektivitas penerimaan Pajak Bumi dan Bangunan (PBB) di Kecamatan Tolangohula Kabupaten Gorontalo, sebagai berikut :

\section{Tahun 2012 :}

$$
\begin{aligned}
\text { Rasio Efektifitas PBB } & =\frac{\text { Rp. 113.892.342,-- }}{\text { Rp. } 145.909 .406} \\
& =0,780 \\
& \text { Atau } 78,0 \%
\end{aligned}
$$

Hasil yang diperoleh pada tahun 2012, rasio efektivitas penerimaan Pajak Bumi dan Bangunan (PBB) di Kecamatan Tolangohula Kabupaten Gorontalo adalah sebesar 0,780 . Oleh karena angka ini kurang dari 1 , atau jika dikalikan 100 hasilnya sebesar $78,0 \%$. Dengan demikian dapat dikatakan bahwa penerimaan Pajak Bumi dan Bangunan (PBB) di Kecamatan Tolangohula Kabupaten Gorontalo pada tahun 2012 kurang efektiv. Hal ini disebabkan oleh adanya target yang sangat besar ditetapkan oleh pemerintah daerah, sedangkan realisasinya masih kurang. Selain itu masih kurang tersedianya infrastruktur yang mendukung pada tempat pelelangan ikan menyebabkan rendahnya relaisasi penerimaan Pajak Bumi dan Bangunan (PBB) di Kecamatan Tolangohula Kabupaten Gorontalo.

Tahun 2013 :

Rasio Efektifitas PBB

$$
\begin{aligned}
= & \frac{\text { Rp. 142.242.440,- }}{\text { Rp. 151.114.251,- }} \\
= & 0,941 \\
= & 94.1 \%
\end{aligned}
$$

Hasil yang diperoleh pada tahun 2013, rasio efektivitas penerimaan Pajak Bumi dan Bangunan (PBB) di Kecamatan Tolangohula Kabupaten Gorontalo adalah sebesar 0,941. Oleh karena angka ini kurang dari 1, atau jika dikalikan 100 hasilnya sebesar 94.1\%. Dengan demikian dapat dikatakan bahwa penerimaan Pajak Bumi dan Bangunan (PBB) di Kecamatan Tolangohula Kabupaten Gorontalo pada tahun 2013 berada pada kategori efektiv.

Hal tersebut diatas disebabkan oleh adanya target retribusi tempat pelelangan ikan (TPI) yang naik dari tahun sebelumnya, adapun realisasinya meningkat dari tahun sebelumnya. 
Tahun 2014 :

Rasio Efektifitas PBB

$$
\begin{aligned}
& =\frac{\text { Rp. 142.255.179,-- }}{\text { Rp._142.255.179,-- }} \\
& =1 \\
& =100 \%
\end{aligned}
$$

Hasil yang diperoleh pada tahun 2014, rasio efektivitas penerimaan Pajak Bumi dan Bangunan (PBB) di Kecamatan Tolangohula Kabupaten Gorontalo adalah sebesar 1. Oleh karena angka ini dikalikan 100 hasilnya sebesar $100 \%$. Dengan demikian dapat dikatakan bahwa penerimaan Pajak Bumi dan Bangunan (PBB) di Kecamatan Tolangohula Kabupaten Gorontalo pada tahun 2014 sudah sangat efektiv.

Hal ini disebabkan oleh adanya target yang sangat besar ditetapkan oleh pemerintah daerah dibandingkan tahun sebelumnya, sedangkan realisasinya masih kurang meskipun ada peningkatan realisasi dari tahun sebelumnya.

Dari hasil analisis efektivitas penerimaan Pajak Bumi dan Bangunan (PBB) di Kecamatan Tolangohula Kabupaten Gorontalo pada tahun 2012-2014, maka dapat disajikan dalam tabel berikut ini :

Tabel 5.7 Efektivitas Penerimaan Pajak Bumi dan Bangunan (PBB)

Kecamatan Tolangohula Kabupaten Gorontalo

\begin{tabular}{|c|c|c|c|}
\hline NO & TAHUN & $\begin{array}{c}\text { RASIO } \\
\text { EFEKTIVITAS } \\
\text { PENERIMAAN PBB } \\
(\mathbf{\% )}\end{array}$ & KETERANGAN \\
\hline 1 & 2012 & 78.06 & Cukup Efektiv \\
\hline 2 & 2013 & 94.13 & Efektiv \\
\hline 3 & 2014 & 100 & Sangat Efektiv \\
\hline
\end{tabular}

Sumber : Data Diolah Tahun 2016

Berdasarkan tabel diatas, dapat dijelaskan bahwa pada tahun 2012 rasio efetivitas penerimaan Pajak Bumi dan Bangunan (PBB) di Kecamatan Tolangohula Kabupaten Gorontalo adalah sebesar 78,06\% atau cukup efektiv. Pada tahun 2013 rasio efektivitas penerimaan Pajak Bumi dan Bangunan (PBB) di Kecamatan Tolangohula Kabupaten Gorontalo adalah sebesar 94,13\% oleh karena itu maka dapat dikatakan penerimaan Pajak Bumi dan Bangunan (PBB) di Kecamatan Tolangohula Kabupaten Gorontalo pada tahun ini sudah efektiv dan selanjutnya pada tahun 2014, rasio efektivitas penerimaan Pajak Bumi dan Bangunan (PBB) di Kecamatan Tolangohula Kabupaten Gorontalo adalah sebesar 100\% atau sangat efektiv.

Adapun efetivitas penerimaan Pajak Bumi dan Bangunan (PBB) di Kecamatan Tolangohula Kabupaten Gorontalo dirinci per desa yang ada, akan nampak pada tabel berikut ini : 
Tabel 5.8 Efektivitas Penerimaan Pajak Bumi dan Bangunan (PBB)

Dirinci Per Desa di Kecamatan Tolangohula

\begin{tabular}{|c|l|c|c|c|}
\hline \multirow{2}{*}{ NO } & \multirow{2}{*}{ DESA } & \multicolumn{3}{c|}{ RASIO EFEKTIVITAS } \\
\cline { 3 - 5 } & & $\mathbf{2 0 1 2}$ & $\mathbf{2 0 1 3}$ & $\mathbf{2 0 1 4}$ \\
\hline 1 & Gandasari & 50.32 & 100 & 100 \\
\hline 2 & Sukamakmur & 36.8 & 70.24 & 100 \\
\hline 3 & Molohu & 80.24 & 100 & 100 \\
\hline 4 & Lakeya & 64.42 & 100 & 100 \\
\hline 5 & Binajaya & 100 & 100 & 100 \\
\hline 6 & Polohugo & 100 & 100 & 100 \\
\hline 7 & Tamaila & 77.52 & 100 & 100 \\
\hline 8 & Sidoharjo & 100 & 100 & 100 \\
\hline 9 & Sukamakmur & 86.7 & 100 & 100 \\
\hline 10 & Utara & 100 & 76.72 & 100 \\
\hline 11 & Margomulya & 100 & 100 & 100 \\
\hline 12 & Gandaria & 100 & 100 & 100 \\
\hline 13 & Ombulotango & 80.11 & 100 & 100 \\
\hline 14 & Tamaila Utara & 100 & 100 & 100 \\
\hline 15 & Himalaya & 87.89 & 100 & 100 \\
\hline
\end{tabular}

Sumber : Data Diolah Tahun 2016

Dari tabel diatas dapat dilihat bahwa, Desa Binajaya, Desa Polohungo, Desa Sidoharjo, Desa Makmur Abadi, Desa Gandaria, dan Desa Tamaila Utara adalah Desa dengan rasio penerimaan Pajak Bumi dan Bangunan (PBB) di Kecamatan Tolangohula yang sangat efektiv, dimana dari tahun 2012 sampai 2014 pemungutan PBB mencapai $100 \%$. Sedangkan Desa Sukamakmur mencatat rasio kurang efektiv selama tahun 2012 dan 2013 meskipun pada tahun 2014 mejadi sangat eketiv.

Selanjutnya dari tabel diatas juga nampak bahwa penerimaan Pajak Bumi dan Bangunan (PBB) di semua desa yang ada di Kecamatan Tolangohula Tahun 2014 menunjukan hasil yang sangat efektiv atau 100\%.

\section{SIMPULAN DAN SARAN}

\subsection{Simpulan}

Berdasarkan uraian-uraian yang telah dikemukakan pada beberapa bagian terdahulu dari penelitian ini, maka kesimpulan penelitian ini adalah:

1. Realisasi penerimaan Pajak Bumi dan Bangunan (PBB) di Kecamatan Tolangohula Kabupaten Gorontalo, terlihat bahwa meskipun terjadi kenaikan selama tahun 2012-2014 namun kenaikannya belum terlalu besar, dimana pada tahun 2012 adalah sebesar Rp. 113.892.342,- dan kemudian meningkat pada tahun 2013 menjadi sebesar Rp. 142.242.440,- serta selajutnya pada tahun tahun 2014 realiasi penerimaan PBB di Kecamatan Tolangohula kembali naik meski sedikit yaitu menjadi Rp. 142.255.179,. Hal ini karena mengingat penetapan besaran Pajak Bumi dan Bangunan (PBB) disesuaikan dengan Nilai Jual Objek Pajak (NJOP) di Kecamatan Tolangohula yang masih rendah. 
2. Rasio efektivitas penerimaan Pajak Bumi dan Bangunan (PBB) di Kecamatan Tolangohula tahun 2012-2014 menunjukan peningkatan yang baik, dimana tahun 2012 rasio efetivitas penerimaan Pajak Bumi dan Bangunan (PBB) di Kecamatan Tolangohula Kabupaten Gorontalo adalah sebesar 78,06\% atau cukup efektiv. Pada tahun 2013 rasio efektivitas penerimaan Pajak Bumi dan Bangunan (PBB) di Kecamatan Tolangohula Kabupaten Gorontalo adalah sebesar 94,13\% oleh karena itu maka dapat dikatakan penerimaan Pajak Bumi dan Bangunan (PBB) di Kecamatan Tolangohula Kabupaten Gorontalo pada tahun ini sudah efektiv dan selanjutnya pada tahun 2014, rasio efektivitas penerimaan Pajak Bumi dan Bangunan (PBB) di Kecamatan Tolangohula Kabupaten Gorontalo adalah sebesar $100 \%$ atau sangat efektiv.

3. Dari 15 Desa yang ada di Kecamatan Tolangohula Kabupaten Gorontalo, Desa Binajaya, Desa Polohungo, Desa Sidoharjo, Desa Makmur Abadi, Desa Gandaria, dan Desa Tamaila Utara adalah Desa dengan rasio penerimaan Pajak Bumi dan Bangunan (PBB) di Kecamatan Tolangohula yang sangat efektiv, dimana dari tahun 2012 sampai 2014 pemungutan PBB mencapai 100\%. Sedangkan Desa Sukamakmur mencatat rasio kurang efektiv selama tahun 2012 dan 2013 meskipun pada tahun 2014 mejadi sangat eketiv.

\subsection{Saran}

Dari simpulan yang diuraikan di atas, maka penulis memberikan saran masukan sebagai berikut :

1. Dalam upaya meningkatkan realisai penerimaan Pajak Bumi dan Bangunan (PBB) di Kecamatan Tolangohula Kabupaten Gorontalo, mengoptimalkan kinerja aparat desa, yang dalam hal ini sebagai petugas pemungutan pajak, terutama dalam hal pencatatan perubahan nilai objek pajak yang ada di masing-masing Desa.

2. Selain pencatatan dan pengukuran terhadap objek pajak di desa oleh petugas pajak, diharapkan pula peningkatan peran dalam hal koordinasi pihak kecamatan. Terutama dalam menyampaikan sosialisasi pemungutan pajak dimaksud.

3. Peran pemerintah daerah Provinsi dalam hal pemberian reward kepada kepala desa yang pencapaian penerimaan PBB mencapai 100\% juga perlu ditingkatkan.

\section{Referensi}

Arsyad, Lincolyn, 2010, Ekonomi Pembangunan, edisi Ke III, Bagian Penerbitan STIE YKPN : Yogyakarta.

Arsyad, Lincolyn, 2008, Pengantar Perencanaan Pembangunan Ekonomi Daerah, edisi Ke II, BPFE : Yogyakarta.

Darise, Nurlan, 2011, Pengelolaan Keuangan Daerah, Penerbit PT Index Kolompok Gramedia, Jakarta

Halim, Abdul, 2010, Akuntansi Keuangan Daerah, Salemba Empat, Jakarta

Jhingan, ML, 2010. Ekonomi Pembangunan dan Perencanaan. Jakarta : PT Raja Grafindo Persada

Mahmudi, 2010, Analisis laporan Keuangan Pemerintah Daerah, UPP STIM YKPN, Yogyakarta.

Irawan \& Suparmoko, 2012, Ekonomika Pembangunan, edisi Ke II, BPFE : Yogyakarta

Kuncoro, Mudradjat, 2010, Ekonomi Pembangunan (Teori, Masalah, Dan kebijakan), edisi Ke empat, UPP STIM YKPN : Yogyakarta.

Sidik, Machfud, 2010, Optimalisasi Pajak Dan retribusi Daerah Dalam Rangka Meningkatkan Kemampuan Keuangan Daerah,, Pustaka Sinar Harapan, Jakarta 
Suparmoko. 2010, Ekonomi Publik Untuk Keuangan dan Pembangunan Daerah, penerbit Andi, Yogyakarta

Trihartono, Bambang dkk, 2013, Kekuasaan Penegelolaan Keuangan Negara / Daerah, Penerbit Gramedia, Jakarta.

Sumber Lain :

- Undang-undang Nomor 33 Tahun 2004, Tentang Perimbangan Keuangan Negara dan Daerah

- Undang-undang Nomor 12 Tahun 1957, Tentang Retribusi Daerah

- Undang-Undang Nomor 18 Tahun 1997 tentang Pajak Daerah Dan Retribusi Daerah 